\title{
SISTEM MANAJEMEN KOMUNIKASI DATA JARAK JAUH BERBASIS TEKNOLOGI SMS DAN RADIO TELEMETRY UNTUK PEMANTAUAN KUALITAS AIR
}

\author{
Heru Dwi Wahjono dan Bayu Budiman \\ Peneliti Pada Badan Pengkajian dan Penerapan Teknologi
}

\begin{abstract}
Nowadays the water quality monitoring project that had been doing by government institution is increase due to decreasing of water quality. Many methods and techniques are developed for water quality monitoring. The communication technology development such as GSM/CDMA technology can be used as new network infrastructure for water quality monitoring. People over the world are now using this technology as new communication medium. With SMS as the one of services from GSM technology people can send or receive messages easily. By using the integration of digital sensor for water quality, digital data logger and GSM modem as communication unit, the water quality can be monitored as cheap as sending the SMS by phone cell. The critical value of water quality parameter also can be monitored and sent to the phone cell of decision maker.
\end{abstract}

Kata Kunci : Pemantauan Kualitas Air, Teknologi SMS, Radio Telemetry, Early Warning System (EWS), sistem komunikasi GSM (Global System Mobile Communication), SMS (Short Messages Service).

\section{PENDAHULUAN}

\subsection{Latar Belakang}

Dewasa ini sering dijumpai pusat pengumpulan dan pengolahan data jarak jauh (remote) secara realtime/online, atau yang lebih dikenal dengan istilah remote online monitoring system. Sistem online tersebut banyak digunakan terutama untuk pemantauan terhadap suatu obyek, baik obyek diam maupun bergerak, dimana terjadi proses pengiriman data dari obyek di lokasi pemantauan ke pusat pengiriman data. Jarak antara tempat obyek pemantauan biasanya cukup jauh dengan pusat pengolahan data, sedangkan frekwensi pengiriman data dilakukan berdasarkan kebutuhan.

Bentuk data yang dikirim ditentukan berdasarkan parameter apa yang dibutuhkan dari obyek yang dipantau. Hasil pengumpulan data dapat dianalisa untuk proses pengambilan keputusan dan tertentu. Selain itu, sistem monitoring online juga dapat diterapkan di lokasilokasi yang rawan terjadi bencana, seperti banjir, kebakaran hutan, pencemaran lingkungan dan lain sebagainya. Dalam kasus tersebut, sistem online dapat dikategorikan sebagai sistem peringatan dini. Dengan demikian, sistem monitoring online dapat diaplikasikan ke berbagai macam sesuai dengan kebutuhan penggunanya.

Untuk membangun sistem monitoring online dibutuhkan sistem komunikasi data berbasis teknologi elektronik, yaitu perangkat untuk mengambil dan menyimpan data untuk kemudian dikirim ke pusat pengolahan data. Proses pengiriman data ke pusat pengolahan data dapat dilakukan melalui media komunikasi GSM dan radio telemetry. Dari pusat pengolahan data, informasi dapat ditristribusikan ke pengguna lain melalui berbagai media komunikasi, seperti GSM dan internet.

\subsection{Tujuan}

Sistem komunikasi data memiliki tujuan umum yaitu menyajikan data primer dari hulu sampai ke hilir secara cepat, tepat, akurat dan berkesinambungan. Dengan demikian, informasi akan dapat cepat sampai ke pengambil kebijakan. Sedangkan tujuan khusus dari sistem komunikasi data tersebut adalah :

- Melakukan proses sampling data melalui sensor elektronik untuk kemudian disimpan dalam perangkat data logger.

- Melakukan pengiriman data secara berkala sesuai dengan kebutuhan.

- Melakukan monitoring terhadap parameterparameter tertentu yang dianggap kritis.

- Melakukan respon terhadap situasi tertentu yang dianggap beresiko, dimana nilai kritis dari suatu parameter terlampaui, seperti membunyikan sirene, mengaktifkan alat pemadam kebakaran, mematikan aliran listrik, mengirimkan berita melalui SMS dan lain sebagainya.

- Melakukan proses penyimpanan data monitoring dalam jumlah besar di pusat pengolahan data. 


\subsection{Metodologi}

Metode yang dipakai dalam melakukan kegiatan ini secara umum adalah :

1. Proses pengambilan sampel data. Proses ini merupakan proses awal di lokasi pemantauan. Untuk pengambilan data digunakan alat sensor elektronik, yang bertugas merubah satuan parameter ke dalam satuan elektronik yang kemudian dikonversi ke dalam data digital. Jenis sensor yang digunakan tergantung dari jenis data apa yang akan dimonitor, misalnya saja sensor suhu untuk memonitor suhu, sensor $\mathrm{pH}$, sensor kadar Oksigen dan lain-lain.

2. Proses penyimpanan data lokal. Data digital yang dihasilkan dari sensor elektronik kemudian dikirm ke penyimpanan data lokal atau yang dikenal dengan istilah perangkat data logger. Perangkat ini kemudian menyimpan data digital ke dalam memori internal. Apabila data sudah terkumpul, maka data akan disusun ke dalam format tertentu untuk kemudian dikirim ke pusat pengolahan data. Penyimpanan data di memori lokal data logger dilakukan secara berkala dalam waktu yang telah ditentukan sebelumnya, misalnya setiap 1 jam sekali atau 30 menit sekali. Semakin sering data logger menyimpan data maka semakin sering juga data logger mengirim data ke pusat pengolahan data. Hal ini tentunya berdampak pada biaya operasional untuk pengiriman data.

3. Proses pengiriman data. Data yang sudah disusun oleh data logger dalam format tertentu kemudian dikirim ke pusat pengolahan data dengan bantuan perangkat komunikasi GSM. Data ini dikirim melalui media perantara SMS. Penyusunan data dalam format tertentu perlu dilakukan karena setiap kali pengiriman SMS kapasitas data terkirim adalah 160 character atau 140 byte data. Karena menggunakan perangkat GSM, perangkat pengiriman data harus ditempatkan di lokasi yang memiliki penerimaan sinyal radio GSM. Apabila di lokasi tersebut tidak memiliki penerimaan sinyal GSM, maka digunakan alat bantu berupa radio telemetry (radio modem) yang akan menghubungkan perangkat data logger dengan perangkat GSM. Contoh kasus ini misalnya pemantauan pencemaran di tengah laut, pemantauan suhu udara di tengah hutan dan lain sebagainya. Untuk penggunaan perangkat radio telemetry, penggunaan frekwensi radio harus melalui prosedur ijin penggunaan frekwensi yag dikeluarkan oleh departemen perhubungan. Hal ini untuk mencegah tumpang tindih antara pengguna frekuensi radio amatir dengan penggunaan frekuensi untuk komunikasi data, sehingga proses pengiriman data tidak terganggu.

4. Proses penyimpanan data. Data yang dikirim ke pusat pengolahan data melalui media perantara SMS akan diterima oleh perangkat GSM (GSM-Modem) yang terhubung ke komputer. Melalui program aplikasi khusus, data ini kemudian disimpan secara otomatis ke dalam basis data monitoring online. Program aplikasi ini juga memantau SMS yang masuk dari pengguna yang memerlukan informasi. Untuk itu diperlukan manajemen pengguna, dimana program aplikasi hanya akan merespon SMS dari pengguna yang memang sudah terdaftar dalam manajemen sistem monitoring online. Dengan demikian, selain menyimpan data monitoring pusat pengolahan data juga melayani informasi yang dibutuhkan oleh para pengguna. Khusus untuk fungsi monitoring stasiun pemantauan, apabila dalam waktu yang terlalu lama tidak terjadi pengiriman data, maka program aplikasi akan mencoba berkomunikasi dengan stasiun pemantauan untuk melakukan pengecekan apakah stasiun pemantauan mengalami gangguan. Apabila ditemukan masalah, maka perlu dilakukan pengecekan ke lokasi tersebut.

Sedangkan metode yang digunakan secara khusus digunakan untuk pemantauan data-data yang memiliki nilai kritis, seperti misalnya pemantauan tingkat pencemaran, pemantauan suhu udara dan lain-lain. Apabila nilai kritis telah terlampaui, tanpa menunggu interval waktu yang telah ditentuikan sebelumnya, data logger akan mengirimkan data ke pusat pengolahan data dengan kode tertentu.

Pusat pengolahan data merespon data yang dikirim dalam kondisi ini (warning) dengan melakukan berbagai aktivitas yang sudah didefinisikan sebelumnya, misalnya membunyikan alarm, mengirimkan berita melalui SMS ke pengambil kebijakan atau instansi yang terkait, misalnya kepolisian, dan lain sebagainya. Data yang dikirim dalam kondisi ini juga disimpan dalam basisdata sistem monitoring online.

\subsection{Lingkup Kegiatan}

Kegiatan pengembangan sistem terdiri dari kegiatan-kegiatan perancangan masingmasing komponennya, yaitu :

- Perancangan arsitektur perangkat keras sistem pemantauan yang meliputi rancangan sistem secara keseluruhan, rancangan data logger dan sistem komunikasi data. 
- Perancangan sistem software yabg meliputi software control untuk pengendalian data logger dan software database monitoring online untuk mengelola data monitoring kualitas air.

\section{PERANCANGAN SISTEM}

\subsection{Arsitektur Sistem}

Arsitektur sistem dapat dibagi menjadi 2 kategori, yaitu sistem yang dioperasikan pada daerah yang memiliki penerimaan sinyal GSM dan sistem yang dioperasikan pada daerah yang tidak memiliki penerimaan sinyal GSM.

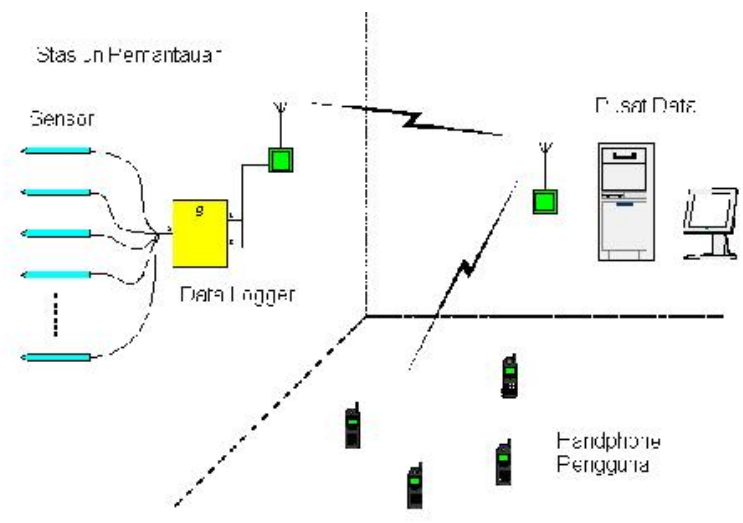

Gambar 1. Arsitektur Sistem Untuk Lokasi Yang Memiliki Penerimaan Sinyal GSM

Pada gambar diatas dapat kita lihat bahwa komunikasi data dari lokasi pemantauan ke pusat pengolahan data murni dilakukan dengan perantaraan media SMS yang dikirim dan diterima oleh perangkat modem GSM. Di lokasi pemantauan, data logger terhubung dengan satu atau beberapa sensor. Pengaturan waktu pengambilan data sepenuhnya dilakukan oleh data logger. Demikian juga pengaturan kapan data logger harus mengirimkan data ke pusat pengolahan data.

Apabila data logger mengirimkan data ke pusat pengolahan data, terjadi komunikasi dua arah, dimana software aplikasi akan memberikan konfirmasi bahwa data sudah diterima dengan baik. Apabila hal ini terjadi, maka data yang tadinya tersimpan di data logger dapat dihapus dengan tujuan untuk mengembalikan kapasitas memori penyimpanan data. Apabila terjadi gangguan komunikasi yang mengakibatkan data tidak diterima oleh komputer pusat pengolahan data, maka data logger akan mengirimkan lagi data yang sama. Hal ini akan dilakukan terus sampai data logger mendapat konfirmasi bahwa data sudah diterima di pusat pengolahan data dengan baik.

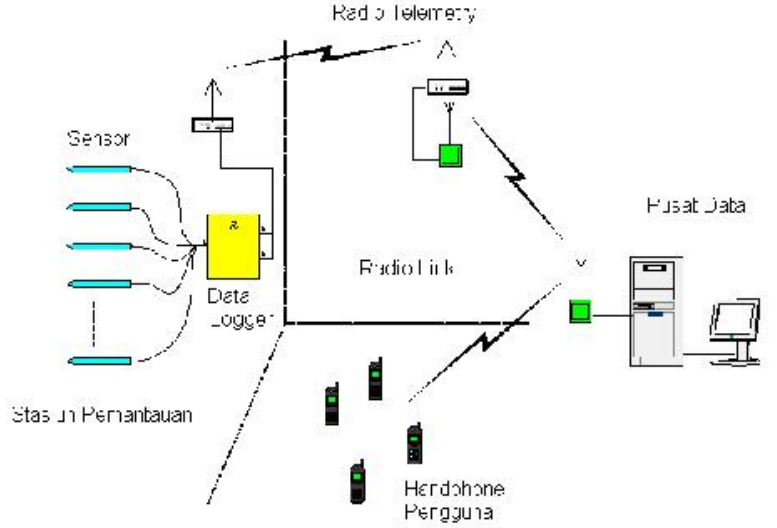

Gambar 2. Arsitektur Sistem Untuk Lokasi Yang Tidak Memiliki Penerimaan Sinyal GSM

Arsitektur sistem pada gambar diatas diterapkan untuk daerah-daerah yang tidak memiliki penerimaan sinyal GSM. Hal ini berlaku untuk lokasi pemantauan lepas pantai, area hutan dan lain sebagainya. Untuk membangun komunikasi antara data logger dengan perangkat GSM dibutuhkan perangkat tambahan yaitu radio telemetry atau yang lebih dikenal dengan istilah radio modem/radio paket. Perangkat ini dapat membangun hubungan data serial tanpa kabel dengan kecepatan 9600 bps.

Untuk mengoperasikan perangkat ini perlu ijin khusus penggunaan frekuensi dari Departemen Perhubungan. Hal ini untuk mencegah tumpang tindih dalam penggunaan frekuensi radio. Kemungkinan lain adalah melakukan kerjasama dengan organisasi radio amatir seperti RAPI atau ORARI. Kedua organisasi ini memiliki kewenangan dalam menggunakan frekuensi radio dengan lebar pita frekuensi diatas $30 \mathrm{MHz}$. Kondisi ini sangat menguntungkan mengingat kebutuhan akan lebar pita frekuensi untuk radio telemetry sangat kecil, sehingga ada kemungkinan kedua organisasi ini bersedia memberikan frekuensi tertentu yang dapat digunakan untuk komunikasi data sejauh kegiatan ini bukan bersifat komersil.

\subsection{Teknologi Komunikasi GSM}

Teknologi GSM merupakan salah satu teknologi komunikasi data yang paling banyak diterapkan untuk komunikasi telepon genggam. Teknologi ini merupakan teknologi generasi ke 3 (3G) yang saat ini paling banyak digunakan, yaitu kurang lebih 120 juta pengguna di seluruh dunia dan di sekitar 120 negara. ${ }^{(1)}$ Selain biayanya murah, bermacam-macam fasilitas dapat diberikan oleh teknologi ini, di antaranya adalah akses jaringan global internet dan layanan SMS (Short Message Service).(2) Layanan SMS yang disediakan memiliki kapasitas 140 byte data, 
yaitu sekitar 140 160 karakter dalam sekali pengiriman dengan biaya pengiriman berkisar Rp. $150 \sim$ Rp. 350. Jumlah 160 karakter ini cukup untuk mengirimkan informasi pengukuran kualitas air yang berisi data-data : nomor stasiun, tanggal dan jam pengukuran serta beberapa parameter hasil pengukuran kualitas.

Selain banyaknya operator penyedia jasa telekomunikasi GSM yang memberikan berbagai peringkat pilihan harga, juga cakupan wilayahnya dapat mencapai ke seluruh pelosok di daerah terpencil sekali pun. Perangkat telepon genggam yang ada di pasaran dapat digunakan sebagai alat pengirim data menggunakan multi mode frekwensi yang disediakan oleh operator telekomunikasi. Untuk jaringan GSM disediakan mode frekwensi dari $900 \mathrm{MHz}, 1.800 \mathrm{MHz}$ sampai $1.900 \mathrm{MHz}$. ${ }^{(3)}$

\subsection{Spesifikasi Perangkat Sistem}

Dalam pembangunan sistem komunikasi data untuk proses monitoring online, pemilihan perangkat keras yang digunakan disesuaikan dengan kebutuhan sistem. Berikut ini adalah spesifikasi perangkat keras yang digunakan untuk komunikasi data sistem monitoring online kualitas air :

\section{Sensor Elektronik}

Sensor adalah alat yang bertugas merubah satuan parameter tertentu ke satuan listrik seperti tegangan dan arus. Pada umumnya ada beberapa jenis sensor yang dapat digunakan untuk pemantauan online yaitu :

\section{- Sensor Analog}

Sensor ini merupakan sensor yang paling sederhana. Keluaran sinyal yang dihasilkan adalah sinyal tegangan listrik yang berkisar antara $-10-10$ volt. Sebelum dikirim ke data logger, sinyal terlebih dahulu dikonversi ke data digital dengan menggunakan $A / D$ Converter. Untuk parameter tertentu, data yang masuk kemudian dikonversi lagi dengan menggunakan bantuan tabel yang biasanya disertakan pada sensor analog. Penggunaan sensor analog memakan biaya yang relatif murah, hanya untuk implementasinya dibutuhkan teknik yang agak rumit.

\section{- Sensor Digital}

Sensor ini memiliki $A / D$ converter, sehingga data yang dihasilkan sudah dalam bentuk format digital. Penyajian data dapat dilakukan secara langsung melalui display angka, atau secara tidak melalui ekstra modul untuk penyajian data. Untuk sensor digital model kedua biasanya memiliki sarana komunikasi RS-232 dan banyak digunakan untuk proses pemantauan data jarak jauh (digital sensor module), sedangkan sensor model pertama banyak digunakan untuk pengambilan data secara langsung (portable sensor).

Untuk kebutuhan pemantauan kondisi air digunakan digital sensor module multi probe dengan parameter yang dipantau adalah : suhu, pH, TDS, DO dan salinitas. Sensor ini memiliki spesifikasi khusus untuk penggunaan di air laut yang pada umumnya memiliki tingkat kadar garam tinggi. Untuk komunikasi dengan data logger, sensor ini memiliki koneksi RS-232. Proses pengukuran dan pengambilan data dari sensor dikendalikan sepenuhnya oleh data logger.

\section{Data Logger}

Data logger yang digunakan memiliki koneksi (port) dan spesifikasi sebagai berikut :

- RS-232 port : 1 main , 3 slave

- 8 channel analog port

- 8 bit optocoupler TTL input, dapat diextend menjadi 40 bit

- 4 bit Transistor output, dapat di-extend menjadi 20 bit

- 256 kByte flash memori

- Real Time Clock

- Memiliki fungsi PLC untuk proses kontrol dan warning system

\section{GSM Modem}

Modem GSM dengan frekuensi $900 \mathrm{MHz}$, sim-card dari salah satu operator GSM berikut : TELKOMSEL, SATELINDO, atau EXELKOMINDO. Komunikasi ke data logger melalui RS-232 dengan kecepatan 9600 atau 19200 bps. Dapat juga digunakan perangkat handphone yang memiliki fungsi modem di dalamnya

\section{Radio Telemetry}

Untuk koneksi nirkabel antara data logger dengan GSM Modem akan digunakan perangkat radio modem dengan spesifikasi berikut :

- Komunikasi point to point

- Frekuensi single atau multi (hoping)

- Alokasi frekuensi antara $380-450 \mathrm{MHz}$, tergantung dari pengalokasian instansi yang berwajib

- Lebar pita frekuensi max. $25 \mathrm{kHz}$

- Carier Power $10 \mathrm{~mW}$ - $1 \mathrm{~W}$

- $\quad$ Radio sensitivity $-115 \mathrm{dBm}(\mathrm{BER}<10 \mathrm{E}-3)$ 
- Jangkauan pada pandangan bebas (line of sight) $\max 40 \mathrm{~km}$

\section{Power Management}

Untuk lokasi pemantauan yang tidak memiliki suplai listrik dari jaringan PLN, maka Sensor, Data Logger beserta seluruh perangkat komunikasi harus memiliki suplai listrik sendiri. Suplai listrik dapat diperoleh dengan menggunakan aki kering yang akan memberikan suplai listrik selama 24 jam. Untuk mengisi aki yang telah dipakai, maka digunakan panel surya (solar cell) yang terhubung dengan aki kering melalui pengontrol tegangan (Voltage Regulator). Proses pengisian aki sendiri diatur melalui fungsi PLC yang terdapat di dalam Data Logger. Sehingga sistem pemantauan dapat beroperasi minimal selama lebih dari 12 bulan tanpa melakukan penggantian aki kering. Jenis aki kering yang digunakan adalah aki 12 volt dengan kapasitas 6 Ah, sedangkan panel surya yang digunakan memiliki kapasitas daya $10-25$ watt.

6. Unit Pengolahan Data

Untuk penerimaan dan pengolahan data yang masuk melalui SMS, pada pusat pengolahan data dibutuhkan :

- Personal Komputer dengan spesifikasi minimum : Pentium III - $1 \mathrm{GHz}, 128$ Mbyte RAM, 10 Gbyte Hardisk

- 1 Unit GSM Modem

- Sistem Operasi Windows XP atau 2000

- Software database : MS-Access / MySQL / SQL-Server / Oracle dsb.

- Software Aplikasi SMS

- Software Aplikasi Pengolahan dan Penyajian Informasi dalam bentuk grafik

- Software Aplikasi Web-Server untuk publikasi data ke internet.

\section{IMPLEMENTASI SISTEM}

Untuk proses implementasi sistem komunikasi data perlu dilakukan tahapan sebagai berikut :

\section{Kalibrasi Sensor}

Sebelum sensor digunakan, sensor harus terlebih dahulu dikalibrasi agar data yang dihasilkan dari pengukuran tidak menunjukkan angka yang keliru. Proses kalibrasi dilakukan dengan menempatkan sensor pada media yang sudah kita ketahui besarannya, misalnya pada suhu udara tertentu, kemudian nilai besaran yang kita ketahui dimasukkan ke dalam sensor, dimana nilai tersebut nantinya akan menjadi nilai acuan (reference value). Pada sensor yang digunakan untuk pemantauan kondisi air, yaitu digital sensor multi probe, dimana sensor memiliki beberapa pengukur, yaitu suhu, pH, DO, TDS, konduktifitas dan salinitas, maka proses kalibrasi juga harus dilakukan pada masing-masing parameter tersebut. Setelah itu, dilakukan pengetesan untuk melihat apakah data-data yang dihasilkan oleh sensor menunjukkan nilai yang benar. Untuk proses kalibrasi, sensor dapat dihubungkan ke komputer dan komunikasi dilakukan melalui RS-232 dengan bantuan windows-software hyper terminal.

\section{Koneksi Sensor Ke Data Logger}

Data Logger yang digunakan dapat dihubungkan ke semua jenis sensor seperti dijelaskan pada sub bagian Spesifikasi Perangkat Sistem. Hal ini disebabkan karena Data Logger memiliki berbagai macam port komunikasi.

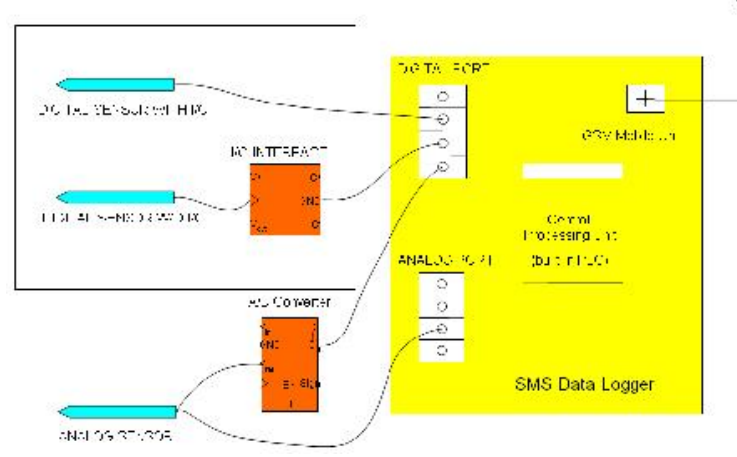

Gambar 3. Konektivitas Antara Berbagai Macam Sensor Dengan Data Logger

Koneksi antara sensor yang digunakan untuk pembangunan prototipe pemantauan online kualitas air (digital sensor module) dengan Data Logger dilakukan melalui port RS-232. Digital sensor dihubungkan ke salah satu dari tiga slave RS-232 port.

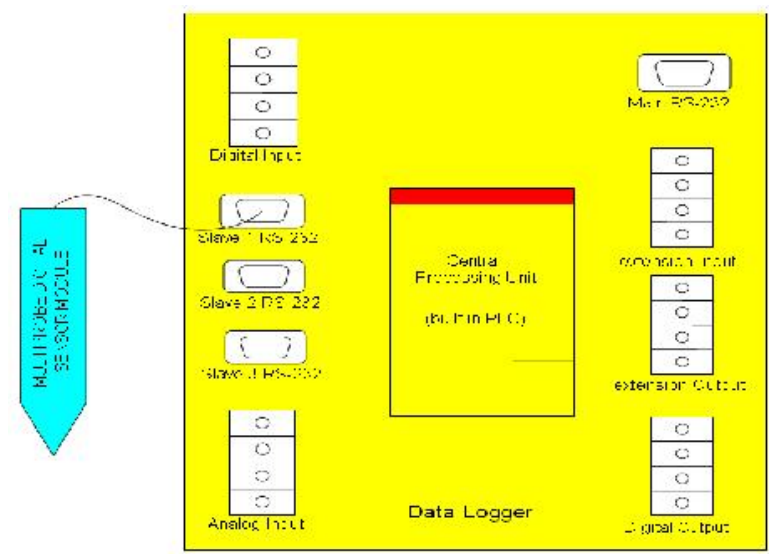

Gambar 4. Konektivitas Antara Multiprobe Digital Sensor Module Dengan Data Logger 


\section{Setting Data Logger}

Setting yang dilakukan pada Data Logger mencakup parameter :

- Interval waktu pengambilan data dari sensor

- Kapasitas data yang dikirim melalui SMS

- Jenis parameter dan besarnya nilai kritis yang dimonitor

- Sinkronisasi waktu dengan jam pada PC di pengolahan data

- Pemrograman PLC untuk sistem peringatan dini

4. Koneksi Data Logger Ke GSM Modem Secara Langsung

Untuk daerah pemantauan yang memiliki sinyal penerimaan GSM, maka Data Logger dapat dihubungkan langsung ke perangkat GSM Modem. Koneksi dilakukan melalui main RS-232 di Data Logger dengan menggunakan kabel data serial yang terhubung ke GSM Modem.

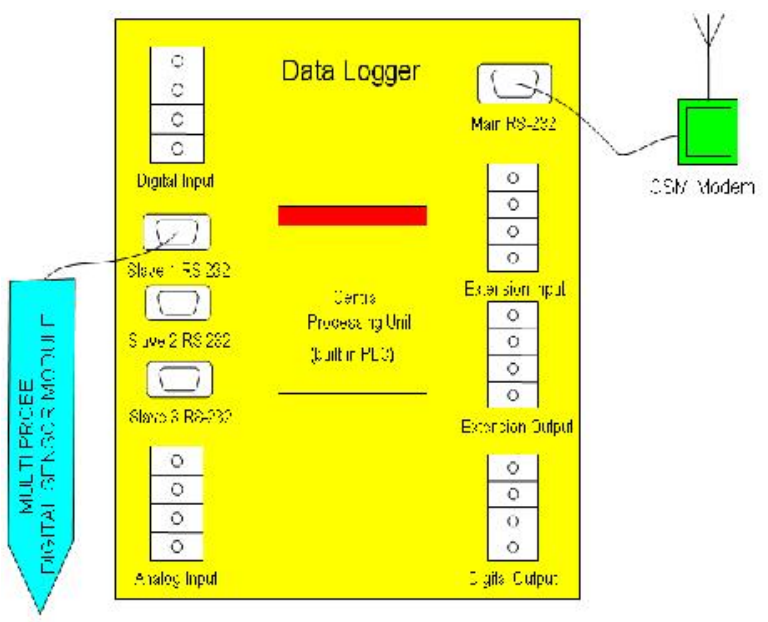

Gambar 5. Konektivitas Langsung Antara Data Logger Dengan GSM Modem

5. Koneksi Data Logger Ke GSM Modem Melalui Radio Modem

Penggunaan Radio Modem pada prinsipnya menggantikan kabel data yang menghubungkan Data Logger dengan GSM Module yang disebabkan ketidak-tersedianya penerimaan sinyal GSM di lokasi pemantauan. Perangkat GSM Modem dengan demikian akan ditempatkan di daerah yang berada dalam jangkauan sinyal GSM. Sedangkan untuk perangkat radio modem akan dilengkapi dengan antena. Jenis antena yang digunakan mulai dari jenis antena dipol biasa yang memiliki karakteristik pancaran sinyal omni-directional, sampai ke antena dengan characteristic directed, dimana sinyal radio hanya dipancarkan ke satu arah tertentu (Yagi atau Parabola Antena). Penggunaan
Directed Antena memiliki keuntungan yaitu penerimaan sinyal yang kuat (high gain), akan tetapi antena ini hanya bisa ditempatkan pada objek yang tidak bergerak. Apabila objek yang dilengkapi dengan radio modem merupakan objek bergerak, maka antena yang digunakan adalah antena dipol biasa yang memiliki gain rendah akan tetapi dapat berkomunikasi ke segala arah. Perangkat bantuan lain yang dapat dipakai adalah menara (tower) antena, dimana penggunaannya hanya untuk station yang tidak bergerak (fix radio-station)

6. Konektivitas Untuk Power Management

Untuk memantau kondisi aki yang digunakan untuk suplai listrik, maka tegangan pada aki akan dihubungkan dengan analog input dari data logger. Apabila data logger melihat bahwa tegangan pada aki mulai turun, maka sudah saatnya aki harus diisi kembali oleh panel surya. Hal ini untuk mencegah kerusakan aki kering yang terjadi apabila aki tersebut terlalu sering terhubung dengan panel surya.

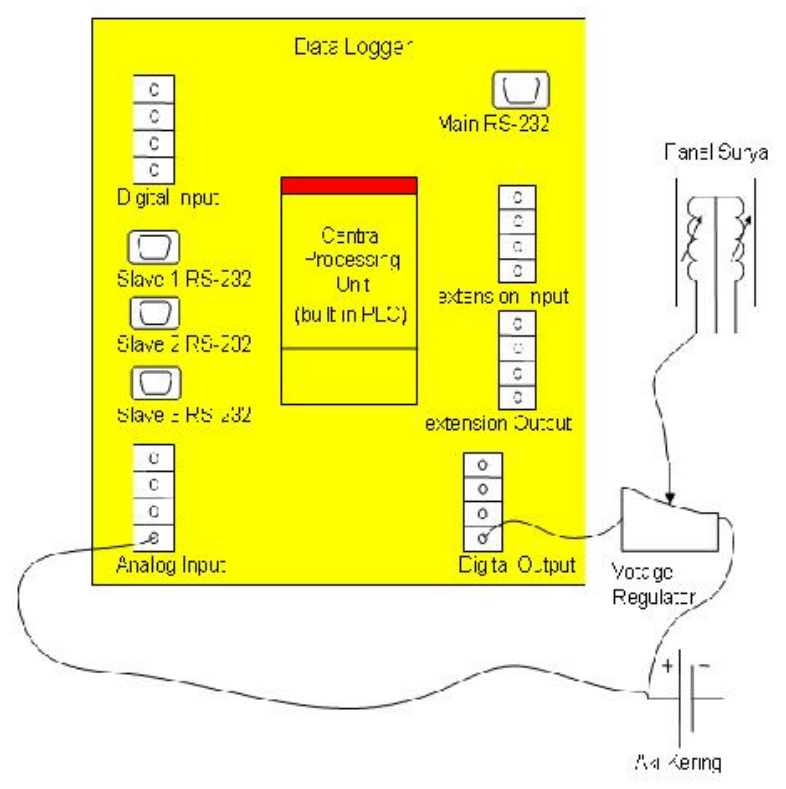

Gambar 6. Konektivitas Antara Data Logger, Aki Kering, Regulator Tegangan Dan Panel Surya

7. Pengembangan Software Aplikasi SMS

Software aplikasi SMS bertugas membaca SMS yang diterima oleh GSM Modem, kemudian menginterpretasikan isi SMS serta nomor pengirim SMS. Apabila nomor pengirim bukan berasal dari nomor yang sudah terdaftar di basisdata, yaitu nomornomor telepon pengguna atau nomor telepon stasiun pemantauan, maka isi SMS akan diabaikan dan dihapus dari memori di GSM Modem. Akan tetapi kalau SMS berasal dari 
nomor komunikasi yang telah terdaftar, maka SMS akan dianalisa, apakah SMS yang masuk berupa data dari stasiun pemantauan atau hanya berupa permintaan informasi dari penggguna.

Data yang dikirim dari stasiun pemantauan langsung diterjemahkan oleh aplikasi SMS dan disimpan dalam basisdata. Tampilan data-data ini bisa disajikan dalam bentuk grafik atau tabel angka.

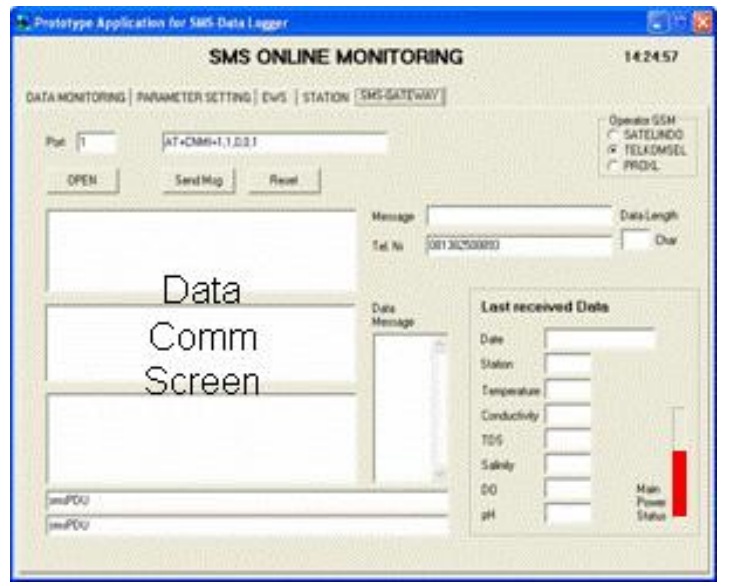

Gambar 7. Protitpe Aplikasi SMS Di Pusat Pengolahan Data

Selain data reguler yang diterima oleh aplikasi SMS, stasiun pemantauan dapat juga mengirim data (critical value) pada kondisi kritis, misalnya pada kondisi dimana terjadi kenaikan nilai $\mathrm{pH}$, temperatur, atau penurunan kadar oksigen dan sebagainya. Data-data ini selain disimpan dalam basisdata juga memberikan sinyal bagi aplikasi SMS untuk melakukan antisipasi, misalnya mengirim SMS ke nomer-nomer tertentu yang memiliki kepentingan dengan fenomena tersebut. Hal ini sangat penting dalam menunjang sistem kontrol terhadap kebersihan lingkungan.

8. Pengembangan Database

Basisdata yang terdapat di pusat pengolahan data memuat data-data yang dikirim oleh stasiun pemantauan. Data dasar yang dikirimkan oleh stasiun pemantauan adalah nomor identifikasi stasiun pemantauan, nilai besaran beberapa paramater yang dipantau beserta tanggal dan jam pengambilan data di lokasi pemantauan. Masing-masing stasiun pemantauan memiliki nomor kode data tertentu. Pengembangan basisdata sangat tergantung dengan kebutuhan pengguna sistem, karena hal ini sangat terkait dengan kebutuhan akan penyajian informasi dalam format tertentu.

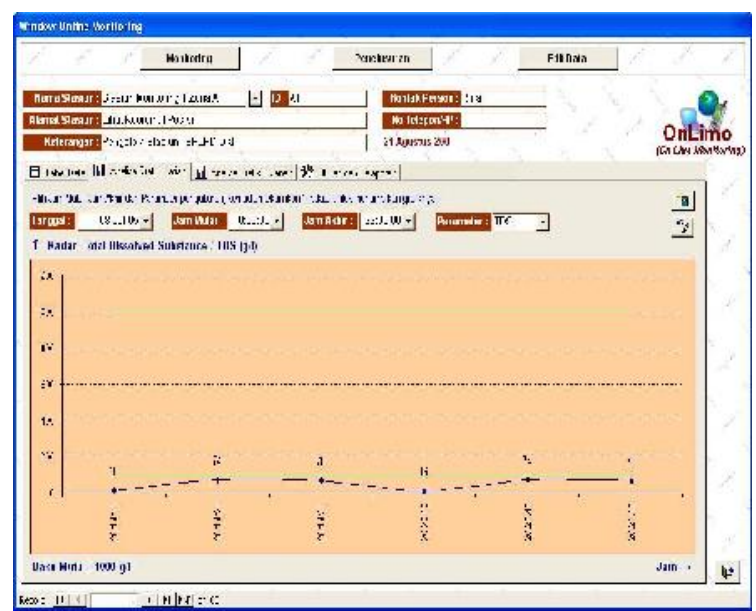

Gambar 8. Prototipe Software Database

\section{UJI COBA SISTEM}

Setelah selesai dilakukan setting atau kalibarsi pada masing-masing perangkat dan saling terhubung satu sama lain, maka dapat dilakukan uji coba sistem. Yang pertama kali dapat dilakukan adalah mencoba mengirim SMS dari aplikasi ke Data Logger, dimana Data Logger harus merespon SMS tersebut.

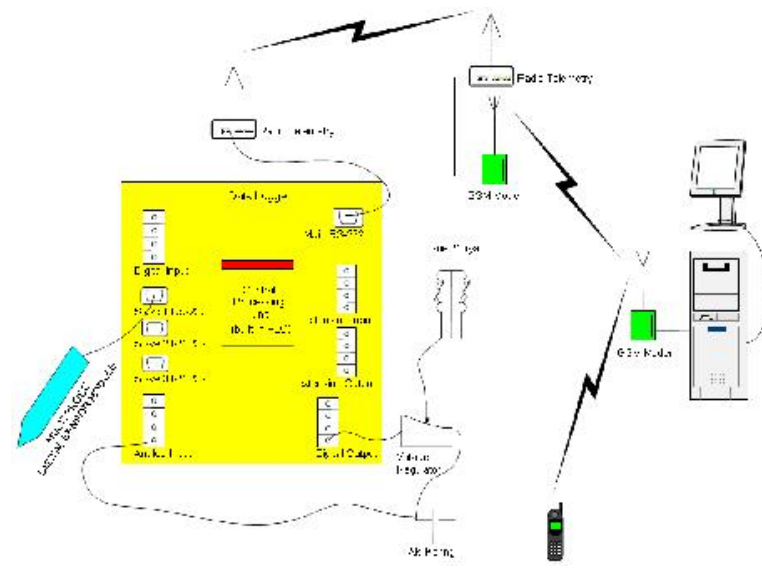

Gambar 9. Protitpe Sistem Komunikasi Data Untuk Pemantauan Kualitas Air

Apabila Komunikasi SMS antara pusat pengolahan data dan stasiun pemantauan sudah befungsi, Data Logger yang sebelumnya sudah diprogram dapat diujicoba untuk melakukan pengambilan data dari Sensor, dimana data kemudian disimpan sementara di memori lokal. Untuk mempercepat proses pengiriman SMS, interval pengambilan data di Data Logger dibuat kecil, misalnya setiap 5 menit, sehingga dalam waktu kurang dari 30 menit Data Logger sudah harus mengirimkan data ke aplikasi SMS. Data yang masuk kemudian dilihat, apakah sudah otomatis masuk ke database. Apabila hal ini terjadi, maka sistem komunikasi data melalui media SMS sudah dapat dikatakan berfungsi dengan baik. 
Untuk melakukan uji coba power manajemen, maka pengetesan dapat dilakukan dengan menggunakan aki kering yang sudah terpakai lama. Apabila tegangan pada aki kering menurun, maka Data Logger akan mengaktifkan pengatur tegangan (Voltage Regulator) untuk melakukan pengisian listrik ke aki melalui panel surya. Penggunaan power manajemen ini juga dapat diterapkan apabila GSM Modem yang digunakan berupa Handphone biasa, dimana Handphone biasanya memiliki baterei terpisah yang juga harus diisi (charge) apabila tegangan baterei turun ke level minimum. Apabila Data Logger sudah dapat mengontrol pengisian aki kering, maka sistem sudah dapat dioperasikan di tempat yang tidak memiliki suplai listrik.

\section{KESIMPULAN}

Beberapa kesimpulan yang dapat ditarik dari kegiatan ini antara lain :

1. GSM handphone tidak tahan panas. Pada suhu tertentu power mati. Tidak dapat dioperasikan 24 jam. Perlu diganti dengan GSM modem. Alat ini tahan panas dan bisa dioperasikan 24 jam.

2. AT Command pada GSM handphone berbeda dengan GSM modem, sehingga penggantian peralatan ini perlu memodifikasi PLC pada data logger.

3. Umur pemakaian baterei kering \pm 1 tahun dengan pemakaian yang tidak rutin.

4. Perlu dibuat sendiri regulator pengisi baterei dari sumber listrik adaptor agar output listrik yang dikeluarkan stabil 14,5 volt. Regulator akan digunakan juga untuk sumber listrik dari solar cell.

5. PLC (Program Logic Control) pada data logger perlu di-update agar dapat membedakan data yang masuk dari stasiun yang berbeda.

6. Bak kolam untuk pengujian kualitas air perlu dimodifikasi agar dapat digunakan untuk simulasi perubahan kualitas khususnya untuk parameter $D H L, T D S$, Salinitas dan $p H$.

7. Casing peralatan perlu dimodifikasi agar mudah dalam penggantian komponen di dalamnya.
8. Biaya operasional untuk pembelian pulsa dapat lebih murah jika memanfaatkan paket nomor dari satu operator yang sama. Selain itu penghematan biaya pengiriman dapat dilakukan dengan memprogram PLC data logger untuk mengirimkan data satu atau dua kali dalam satu hari.

9. Tidak banyak diperlukan kapasitas media penyimpan data untuk penyimpanan data pengukuran, sehingga proses backup data tidak perlu membutuhkan biaya yang mahal.

10. Untuk keperluan mobile monitoring ke lokasi pengukuran yang menjadi masalah adalah penyediaan sumber listrik. Selain batere yang perlu diisi ulang, mini Genset (450 watt) juga dapat dijadikan alternatif sumber listrik, namun diperlukan ketersediaan bahan bakar bensin untuk menggerakkan Genset.

11. Sistem solar cell untuk alternatif sumber listrik untuk sistem Onlimo dapat digunakan untuk lokasi pengukuran yang terbuka dan mendapatkan sinar matahari langsung.

12. Perlu penyederhanaan tampilan pada software SMS Gateway sebagai sistem data receiver, khususnya pada Tab Control "Parameter Setting".

13. Baik software SMS gateway yang menerima data maupun software database yang mengelola data akan memakai file bersama "Data-Pengukuran.txt" sebagai file data. Kedua software perlu diset hanya dapat membaca data pada sistem dengan Regional Setting "Indonesian". Terutama untuk data angka, karakter koma desimal adalah "," dan karekter titik '.' untuk pemisah digit.

14. Software database terasa lambat untuk menampilkan data secara online dan realtime dalam bentuk grafis. Perlu modifikasi proses penampilan grafik ke layar monitor.

\section{DAFTAR PUSTAKA}

1. Hector D. Calabia (2001), Evolution 2001: CDMA versus GSM

2. Wikipedia (2005), http://en.wikipedia.org/ Short Message Service, Technical Details

3. Wikipedia (2005), http://en.wikipedia.org/ Multi Mode Mobile Phone 


\section{LAMPIRAN}

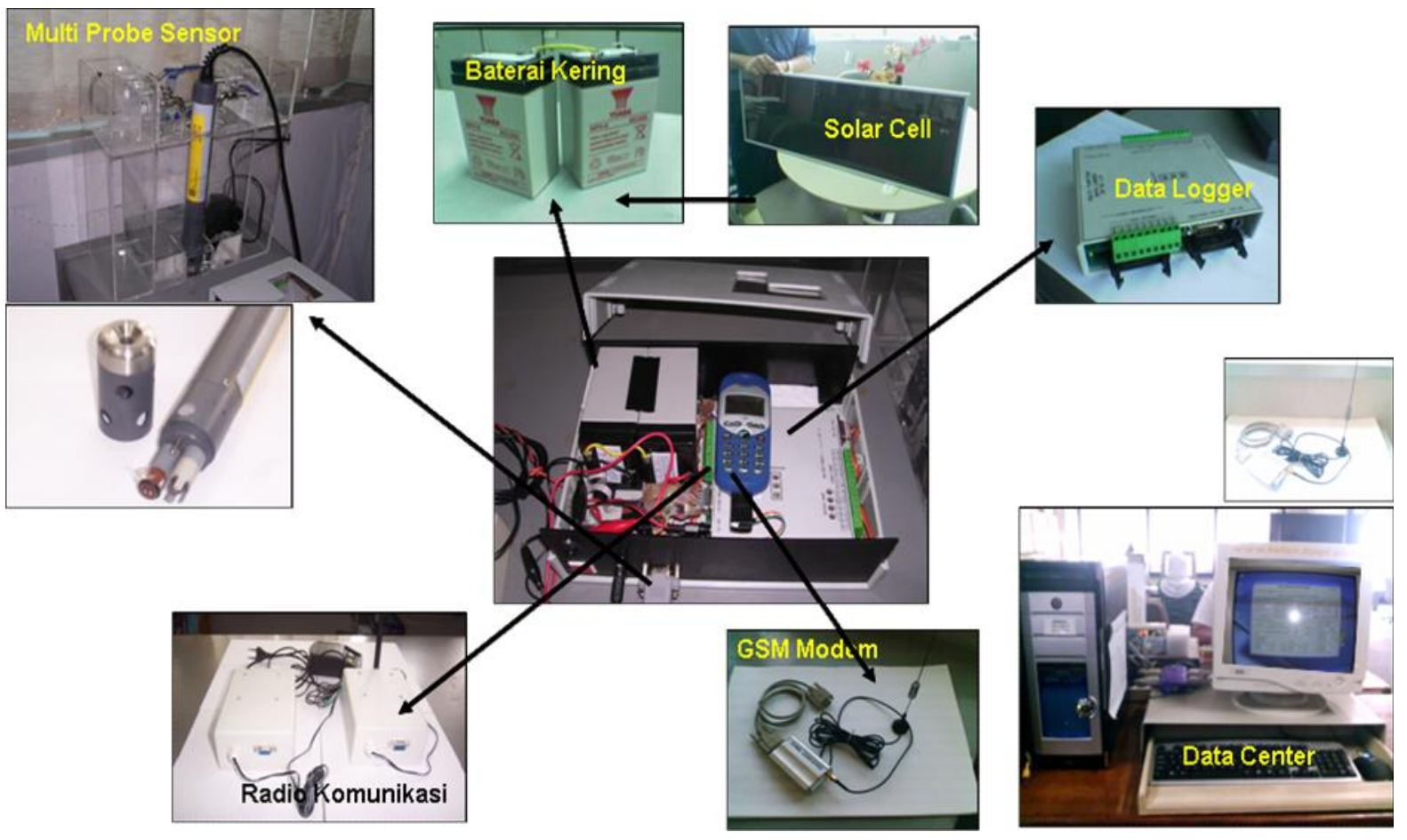

Gambar 10. Komponen Hardware Sistem Pemantauan Kualitas Air Dengan Teknologi GSM
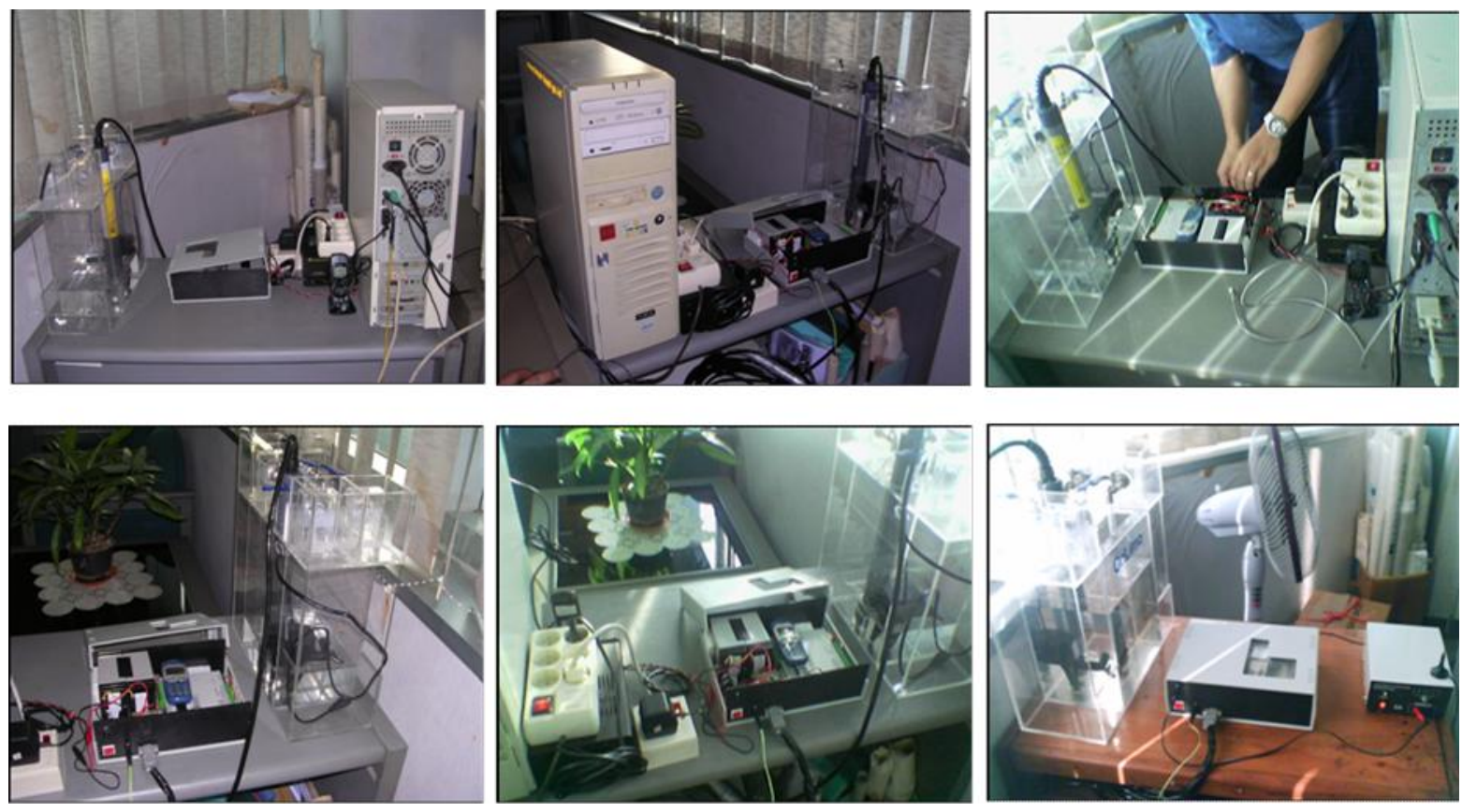

Gambar 11. Foto-foto Kegiatan Uji Coba Sistem Komunikasi Data 